\title{
Evaluating the Effect of Horse Pursulane (Trianthema portulacastrum L.) Competition on Maize (Zea mays L.)
}

\author{
K. Ugalechumi*, V. Geethalakshmi, S. Panneerselvam, C. Chinnusamy, \\ P. Jeyakumar and C.R. Chinnamuthu
}

Tamil Nadu Agricultural University, Coimbatore- 641 003, Tamil Nadu, India

*Corresponding author

\section{A B S T R A C T}

\section{Keywords}

Trianthema

portulacastrum,

Weed density, Yield

loss

Article Info

Accepted:

06 May 2018

Available Online:

10 June 2018

Trianthema portulacastrum L. (Family: Aizoaceae), commonly known as horse pursulane is a troublesome broadleaved weed in India. Aggressive growth of this type of weeds with high invasion potential it becomes an important constraint in crop cultivation. Yield losses are most severe when weeds and crops emerge simultaneously and compete with each other for resources. Crop yield usually decreases with increase in weed density and interference duration. The competition effect of Horse pursulane on growth and yield attributes of maize experiment was conducted during January 2018 at Agricultural College and Research Institute, Tamil Nadu Agricultural University, Madurai. Treatments like weed free check, horse pursulane densities (7, 14, 21, 28 and $35 \mathrm{~m}^{-2}$ ) and unweeded check were laid out in Randamized block design (RBD) with three replications. The results indicated that, higher weed density $\mathrm{m}^{-2}$ reduce the growth parameters like LAI and dry matter production and yield attributes. Weed free check recorded higher grain yield of $8577 \mathrm{~kg} / \mathrm{ha}$. The yield loss $(\%)$ was higher $(44.78 \%)$ in $\mathrm{T}_{6}$ with 35 plants $\mathrm{m}^{-2}$ than other weed density treatments. Horse pursulane infests maize heavily, causing enormous yield losses and threatens the sustainability of maize production.

\section{Introduction}

Maize (Zea mays L.) is one of the most important cereal crops grown all over the globe as poor man's food and also as cattle and poultry feed. It is a versatile crop, allowing it to grow across a wide range of agro ecological zones. Weeds are self-grown and appear simultaneously with crop plant creating severe competition for nutrient, moisture, space and solar energy resulting in reduced crop yield (Umapathy and Sivakumar, 2000). Competition from weeds is most important of all biological factors that reduce agricultural crop yield. This occurs primarily because weeds utilize resources much faster than crops that create competition for resource consumption of crops. The magnitude of yield loss is affected by numerous agronomic and environmental factors, of which weed density and time of emergence relative to the crop causes major yield loss. The season-long weed 
competition caused considerable yield losses in maize of about 35- 70\% (Dalley et al., 2006).

Trianthema portulacasrum is an indigenous plant to South Africa and occurs in India, Pakistan, Bangladesh, Srilanka, West Asia, Africa and Tropical America ((Balyan and Bhan (1986). In India, it is a very common weed of various farm crops, non-crop lands, grasslands and wastelands. It has been observed as a problematic weed in various agricultural crops in the states of Uttar Pradesh, Punjab, Haryana, Rajasthan and Delhi (Aneja et al., 2000, Singh and Prasad, 1994). Horse purslane is a fast-growing, prostrate, profusely branched, succulent, rainy season, and annual broadleaf weed and reaches peak growth within 40-45 days of its emergence and maximum seedling emergence takes place during rainy season in cultivated and wastelands (Balyan and Malik (1989) and Singh and Prasad (1994)). Due to its indeterminate habit, vegetative and reproductive growth continues for the entire life span (Nayyar et al., 2001). The hard seed coat appears to be the primary mechanism of horse purslane dormancy, thus making it a problem for several years and infesting the crops raised subsequently (Umarani and Selvaraj, 1995). Keeping this view the present study was undertaken to study the competition effect of $T$. portulacastrum on maize.

\section{Materials and Methods}

The field experiment was conducted at Agricultural College and Research Institute, Tamil Nadu Agricultural University, Madurai, Tamil Nadu during January to April of 2018 to study the competition effect of Trianthema portulacastrum on maize. The treatments like weed free check, horse pursulane densities ( 7 , 14, 21, 28 and $35 \mathrm{~m}^{-2}$ ) and unweeded check were laid out in Randamized block design (RBD) with three replications. The rotavator was used to form ridges and furrows and the seeds of maize hybrid $\mathrm{CO}$ MH 6 were sown on the sides of the ridges by adopting a spacing of $60 \times 25 \mathrm{~cm}$. Trianthema portulacastrum densities were maintained as per the treatments and all other weeds are removed manually throughout the growing season.

During the course of study data were recorded on dry matter production and LAI of maize at 30, 45 and 60 DAS, and yield attributes, grain yield and yield loss in maize due to $T$. portulacastrum were also examined. The data were analyzed using ANOVA and the least significant difference (LSD) values at 5\% level of significance were calculated.

\section{Results and Discussion}

Significantly higher dry matter production was recorded in less crop weed competition plots than higher weed density plots comparatively. Dry matter production recorded in weed free check at 30, 45 and 60 DAS accounts 1683, 4620 and $6513 \mathrm{~kg} / \mathrm{ha}$ respectively. This is because both the weed species and the crop compete simultaneously for nutrients and moisture. The weed produces higher biomass than crop in its growth period (Jeschke et al., 2009). A reduction in the dry weight of individual plants, probably related to both intraspecific and interspecific competition at higher densities. The results were comparable with the findings of Das (2008).

The leaf area index was significantly higher (1.01) in Weed free check $\left(\mathrm{T}_{1}\right)$ than other treatments at 30 DAS. Weed free check $\left(\mathrm{T}_{1}\right)$ recorded perceptibly higher leaf area index of 4.59 and 5.65 at 45 and 60 DAS respectively and was comparable with Trianthema portulacastrum of 7 plants $/ \mathrm{m}^{2} \quad\left(\mathrm{~T}_{2}\right)$. Irrespective of the stages of observation, besides unweeded check, LAI was discernibly low in Trianthema portulacastrum of 35 
plants $/ \mathrm{m}^{2}\left(\mathrm{~T}_{6}\right)$ among the treatments imposed. A similar effect that was related to a higher density caused a higher reduction in the leaf area (Hazra et al., 2011) (Table 1).

The perusal of data revealed that grain yield of maize was significantly influenced by $T$. portulacastrum densities (Table 2). Weed free check $\left(\mathrm{T}_{1}\right)$ and Trianthema portulacastrum of 7 plants $/ \mathrm{m}^{2}\left(\mathrm{~T}_{2}\right)$ recorded the maximum grain yield of 8577 and $8125 \mathrm{~kg} \mathrm{ha}^{-1}$, respectively. Drastically lower grain yield of $4737 \mathrm{~kg} / \mathrm{ha}$ was obtained from Trianthema portulacastrum of 35 plants $/ \mathrm{m}^{2}\left(\mathrm{~T}_{6}\right)$ and was at par with unweeded check $\left(\mathrm{T}_{7}\right)$. The decreasing in yield with increasing weed density was likely due to interspecific competition for resources (Baye and Bouhache, 2007) (Fig. 1).

Mundra et al., (2003) reported that reduction in crop-weed competition recorded significant increase in the dry matter accumulation and yield attributes which led to significantly higher grain yield.

Table.1 Effect of Trianthema portulacastrum density on leaf area index and dry matter production $(\mathrm{kg} / \mathrm{ha})$ on maize

\begin{tabular}{|c|c|c|c|c|c|c|}
\hline \multirow[t]{2}{*}{ Treatments } & \multicolumn{3}{|c|}{ Leaf Area Index } & \multicolumn{3}{|c|}{ Dry matter production (kg/ha) } \\
\hline & $\begin{array}{c}30 \\
\text { DAS }\end{array}$ & $\begin{array}{c}45 \\
\text { DAS }\end{array}$ & $\begin{array}{c}60 \\
\text { DAS }\end{array}$ & 30 DAS & 45 DAS & 60 DAS \\
\hline$T_{1}-$ Weed free check & 1.01 & 4.59 & 5.65 & 1683 & 4620 & 6513 \\
\hline$T_{2}-T$.portulacastrum of 7 plants $/ \mathrm{m}^{2}$ & 0.76 & 3.72 & 5.30 & 1329 & 4285 & 6320 \\
\hline $\mathrm{T}_{3}-$ T.portulacastrum of 14 plants $/ \mathrm{m}^{2}$ & 0.52 & 3.60 & 4.80 & 1263 & 3373 & 6073 \\
\hline $\mathrm{T}_{4}-$ T.portulacastrum of 21 plants $/ \mathrm{m}^{2}$ & 0.30 & 3.11 & 4.50 & 929 & 2665 & 4920 \\
\hline$T_{5}-T$.portulacastrum of 24 plants $/ \mathrm{m}^{2}$ & 0.27 & 2.95 & 4.15 & 847 & 2532 & 4580 \\
\hline $\mathrm{T}_{6}-$ T.portulacastrum of 35 plants $/ \mathrm{m}^{2}$ & 0.23 & 2.40 & 3.50 & 622 & 1861 & 3367 \\
\hline $\mathrm{T}_{7}$ - Unweeded check & 0.12 & 2.27 & 2.97 & 567 & 1697 & 3133 \\
\hline SEd & 0.04 & 0.13 & 0.17 & 57.16 & 202.40 & 213.11 \\
\hline $\mathrm{CD}(\mathrm{P}=0.05 \%)$ & 0.09 & 0.27 & 0.36 & 124.53 & 441.00 & 464.34 \\
\hline
\end{tabular}

Table.2 Effect of Trianthema portulacastrum density on single cob weight (g), grain yield $(\mathrm{kg} / \mathrm{ha})$ and yield loss \% on maize

\begin{tabular}{|c|c|c|c|}
\hline Treatments & $\begin{array}{c}\text { Single cob weight } \\
\text { (g) }\end{array}$ & $\begin{array}{c}\text { Grain yield } \\
(\mathrm{kg} / \mathrm{ha})\end{array}$ & $\begin{array}{l}\text { Yield loss } \\
(\%)\end{array}$ \\
\hline$T_{1}-$ Weed free check & 183.8 & 8577 & - \\
\hline $\mathrm{T}_{2}-$ T.portulacastrum of $7 \mathrm{plants} / \mathrm{m}^{2}$ & 174.1 & 8125 & 5.28 \\
\hline $\mathrm{T}_{3}-$ T.portulacastrum of $14 \mathrm{plants} / \mathrm{m}^{2}$ & 169.8 & 7924 & 7.62 \\
\hline$T_{4}-T$.portulacastrum of 21 plants $/ \mathrm{m}^{2}$ & 152.3 & 7107 & 17.14 \\
\hline $\mathrm{T}_{5}-$ T.portulacastrum of $24 \mathrm{plants} / \mathrm{m}^{2}$ & 134.8 & 6291 & 26.66 \\
\hline $\mathrm{T}_{6}-$ T.portulacastrum of 35 plants $/ \mathrm{m}^{2}$ & 101.5 & 4737 & 44.78 \\
\hline $\mathrm{T}_{7}$ - Unweeded check & 95.9 & 4475 & 47.82 \\
\hline SEd & 9.15 & 297 & - \\
\hline $\mathrm{CD}(\mathrm{P}=0.05 \%)$ & 19.93 & 647 & - \\
\hline
\end{tabular}


Fig.1 Interaction effect of T. portulacastrum density $\mathrm{m}^{-2}$ on Grain yield $(\mathrm{kg} / \mathrm{ha})$ of Maize

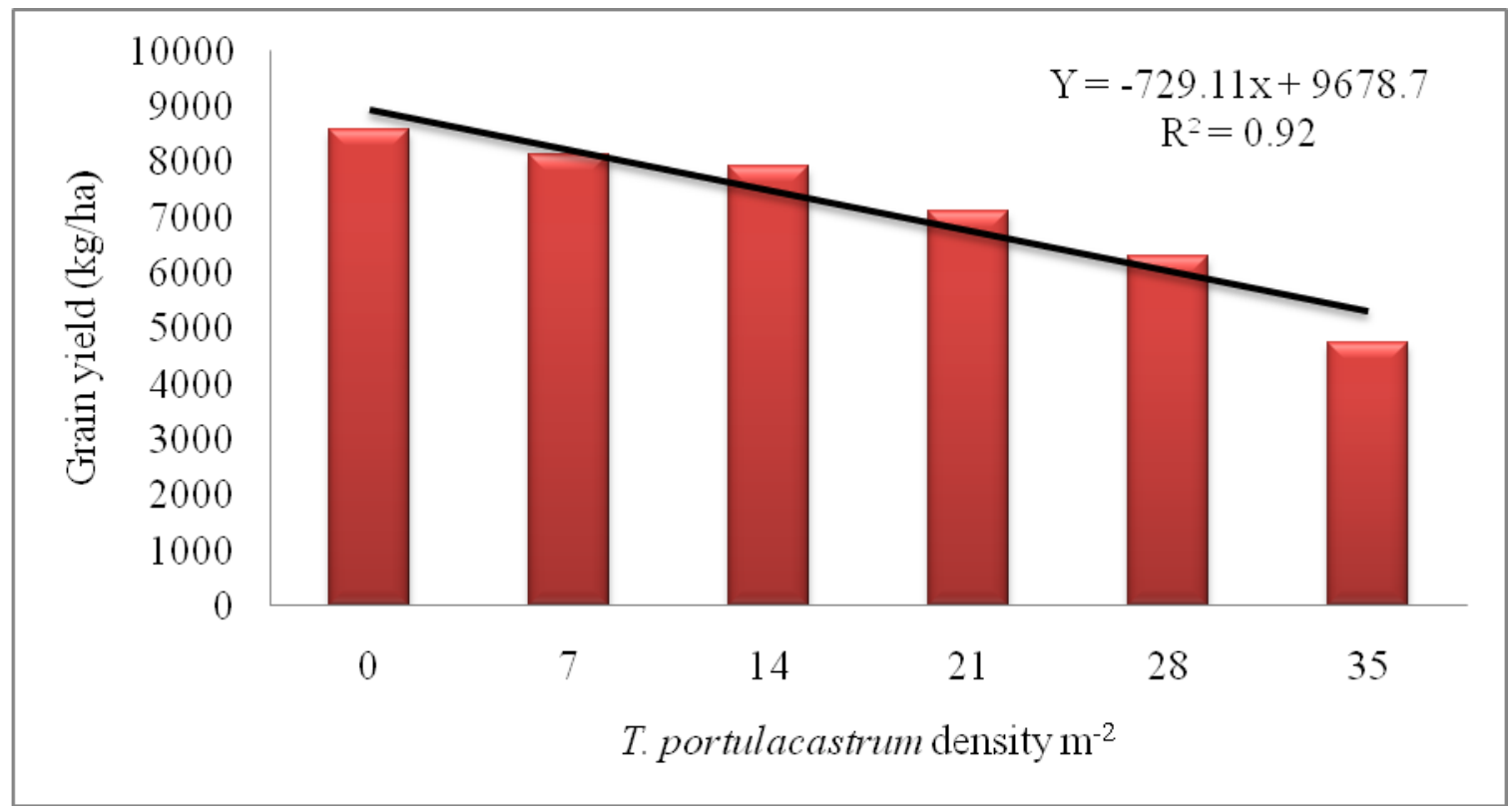

Higher yield loss of $44.78 \%$ was recorded in plot having higher weed Trianthema portulacastrum density of 35 plants $\mathrm{m}^{-2}$ compared to plots have lower weed density of 7 plants $\mathrm{m}^{-2}$ (5.28 \% of yield loss). The decreasing trend in yield due to weed density showed that $T$. portulacastrum affected grain yield with higher yield loss \% reported by (saeed et al., 2010).

It can be concluded that all the $T$. portulacastrum densities were equally competitive to Maize and effectively reducing the yield. Higher grain yield was obtained from $T$. portulacastrum 7 plants $\mathrm{m}^{-2}$ than other weed density treatments, leading to significant reductions in the growth, nutrient uptake, and yield.

However, the actual period before the weeds begin to affect the crop appears to be related to the time taken by $T$. portulacastrum to achieve complete ground cover. For obtaining higher yield of maize the broad leaved weeds may be controlled upto 3 weeks after emergence of the crop as it is found to be the critical period of weed competition for maize.

\section{Acknowledgments}

The first author sincerely acknowledge the contribution to the NATCOM scheme sponsors for their economical support and her sincere thanks to Dr. V. Geethalakshmi and advisory committee members for their moral support and guidance during the course of investigation.

\section{References}

Aneja, K. R., Khan S. A. and Kaushal S. (2000). Horse purslane (Trianthema portulacastrum L.) and its biocontrol with fungal pathogens: an overview. Biocontrol potential and its exploitation in sustainable agriculture, Crop Diseases, Weeds, and Nematodes. Vol. (1): $187-198$

Balyan, R.S. and Bhan, V.M. 1986. Emergence, growth, and reproduction of horse purslane (Trianthema portulacastrum L.) as influenced by environment conditions. Weed Sci, 34: 516-519. 
Balyan, R.S. and Malik, P.K.1989. Control of horse purslane (Trianthema portulacastrum) and barnyard grass (Echinochloa crusgali) in mung bean (Vigna radiata). Weed Sci 37: 695-699.

Baye, Y and Bouhache, M. 2007. Study of the competition of yellow morel and the spring maize. Bull. OEPP, pp. 129-131.

Dalley, C.D., Bernards, M.L and Kells, J.J. 2006. Effect of weed removal timing and spacing on soil moisture in corn (Zea mays).Weed Tech., 20(2): 399409.

Das, T. K. 2008. Weed Science: Basics and Applications. Jain Brothers Publishers, New Delhi, India. p. 901.

Hazra, D., Das, T. K., and Yaduraju, N. T. (2011). Interference and economic threshold of horse purslane (Trianthema portulacastrum) in soybean cultivation in northern India. Weed Biology and Management, 11(2): 72-82.

Jeschke, M.R., Stoltenberg, D.E., Kegode, G.O., Dille, J.A and Johnson, G.A. 2009. Weed community emergence time affects accuracy of predicted corn yield loss by WeedSOFT. Weed Technology 23: 477-485.

Mundra, S.L., Vyas, A.K and Maliwal, P.L.2003. Effect of weed and nutrient management on weed growth and productivity of maize (Zea mays L.). Indian J. Weed Sci., 35 (1\&2): 57-61.

Nayyar, M.N., Ashiq, M and Ahmad, I. 2001. Manual on Punjab Weeds. Vol. 1, Directorate of Agronomy, Ayub Agricultural Institute, Faisalabad, Pakistan. p. 52.

Saeed, M., Marwat, K.B., Hassan, G., Khan, A and Khan, I.A. 2010. Interference of horse purslane (Trianthema portulacastrum L.) with maize (Zea mays L.) at different densities. Pak. J. Bot. 42 (1): 173-179.

Singh, G., and Prasad, R. 1994. Studies on the control of Trianthema portulacastrum L. in fodder maize. Ind. J. Weed. Sci., 26(1\&2): 64-67.

Umapathy, K. and Sivakumar, C.2000. Studies on crop-weed competition in rice - rice cropping system. In: Proceedings of State level seminar on Integrated Weed Management in new millennium, Ratnagiri, Maharastra. 2728, February. p. 57.

Umarani, R and Selvaraj, J. A.1995. Studies on the growth and yield of carpet weed (Trianthema portulacastrum L.) as influenced by soybean (Glycine max (L.) Merrill). Indian J. Weed Sci., 27: 209-10

\section{How to cite this article:}

Ugalechumi, K., V. Geethalakshmi, S. Panneerselvam, C. Chinnusamy, P. Jeyakumar and Chinnamuthu, C.R. 2018. Competition Evaluating the Effect of Horse Pursulane (Trianthema portulacastrum L.) Competition on Maize (Zea mays L.). Int.J.Curr.Microbiol.App.Sci. 7(06): 1119-1123. doi: https://doi.org/10.20546/ijcmas.2018.706.133 